\title{
Is India Financing Urban Transport in the Right Direction?
}

\author{
Aanchal Airy, Gargi Patil
}

\begin{abstract}
Transport issues in urban centers are rising at an exponential rate and are characterized by congestion, high motorized vehicles growth, vehicular and noise pollution, road accidents and parking space constraints. Present public transport and Non-Motorized Transport (NMT) modes are inefficient and do not cater to the needs of $31.23 \%$ of urbanized population in India, which is poised to grow up to $71 \%$ by 2031 (MoUD, 2015). Lack of accessibility in public transport and NMT has compelled commuters to opt for private transport modes such as twowheelers and cars, in order to have access to work, education and other leisure activities.

The paper aims to assess the finances allocated to urban transport system in the city of Pune under the jurisdiction of Pune Municipal Corporation (PMC). The authors intend to critically review the city budget and its contribution to sustainable modes of urban transport. The key research questions are: - a) whether the budget distributes enough revenue to enhance the efficiency and accessibility of public transport modes and NMT as guided in the National Urban Transport Policy (NUTP) of 2006? b) does the local government continue to invest in temporary urban transport solutions catering to the needs of private modes of transportation?

The results further show that PMC's budget allocation is not favoring sustainable modes of transport as much as it is catering to other urban transport infrastructure and utilities. The paper concludes with recommendation on ways of innovative financing methods to make public transport sustainable and discusses various case studies of best practices followed globally pertaining to sustainable urban transport system.
\end{abstract}

\section{Keywords: Financing, Pune, Sustainable, Urban Transport.}

\section{INTRODUCTION}

Urbanization is increasing and therefore migration of people to urban centers is invincible phenomenon in Indian cities, hence demand for transport is likely to overshoot the supply of roads, parking spaces and other transport infrastructure. State Government and Urban Local Bodies (ULBs) are responsible to provide efficient network of sustainable urban transport systems. However, in most of the cities in India, it has been observed that government bodies are heavily investing in construction of roads, bridges and flyovers. With the introduction of National Urban Transport Policy (NUTP) in 2006, emphasis has been given to the promotion of sustainable transport modes such as buses, Bus Rapid Transit System (BRTS), Non-Motorised Transport (NMT) and other mass transit system, simply because they occupy less space, create less congestion and pollution (National Urban Transport Policy, 2006).

Revised Manuscript Received on September 10, 2019.

Dr. Aanchal Airy, Assistant Professor at the Symbiosis School of Economics (SSE), located in Pune, Maharashtra, India.

Gargi Patil, Visiting Faculty at the Symbiosis School of Economics (SSE), located in Pune, Maharashtra,India.
The city of Pune has been selected for analysis considering its national importance as it ranks 2 nd largest city in Maharashtra and 9th in India with regard to population (World Population Review, 2019). The city's metropolitan region has a population of 5,057,709 as per the Census 2011 (Census Population 2015 Data, 2011). Two Municipal bodies namely - Pune Municipal Corporation (PMC) and Pimpri-Chinchwad Municipal Corporation (PCMC) govern Pune metropolitan region. PMC, which was established on 14th February 1950, presently administers an area of $244 \mathrm{sq}$. $\mathrm{km}$. with a population of $31,15,431$ as of 2011 Census (Pune Municipal Corporation, n.d). The growth and percentage change of population in the city of Pune is shown in the Table-I below:

Table- I: Pune Population Growth Trajectory, Area and Density from 1971-2011

\begin{tabular}{ccccccc}
\hline Year & $\begin{array}{c}\text { Population } \\
\end{array}$ & $\begin{array}{c}\text { Growth } \\
\text { rate } \\
(\mathbf{\%})\end{array}$ & Male & Female & $\begin{array}{c}\text { Area (sq. } \\
\text { km) }\end{array}$ & $\begin{array}{c}\text { Density (person } \\
\text { per sq. km) }\end{array}$ \\
\hline $\mathbf{1 9 7 1}$ & 856105 & $41.1 \%$ & NA & NA & 138.76 & 6170 \\
\hline $\mathbf{1 9 8 1}$ & 1203351 & $40.6 \%$ & 631312 & 572039 & 146 & 8242 \\
\hline $\mathbf{1 9 9 1}$ & 1566651 & $40.6 \%$ & 812523 & 754128 & 146 & 11585 \\
\hline $\mathbf{2 0 0 1}$ & 2538473 & $50.1 \%$ & 1321338 & 1217135 & 243.84 & 10410 \\
\hline $\mathbf{2 0 1 1}$ & 3132143 & $22.7 \%$ & 1607812 & 1524331 & 243.84 & 12777 \\
\hline
\end{tabular}

Source: (Pune Municipal Corporation, n.d); (Pune Municipal Corporation, 2012); (Zope, 2013).

The growth rate of the population of Pune city as can be seen in Table-I, reveals a growth of $50.1 \%$ for the decade 1991-2001 and in the subsequent decade of 2001-2011, it can be seen that the growth rate declined to $22.7 \%$. It can also be observed that the city's area has increased from $138.76 \mathrm{sq} \mathrm{km}$ to $243.84 \mathrm{sq} \mathrm{km}$ from 1971 to 2011 . However, the density of population in 2011 standing at 12,777 persons per sq $\mathrm{km}$ went up from 6170 persons per sq $\mathrm{km}$ in 1971, which indicates that it has nearly doubled.

Pune region ranks first in terms of vehicle population in Maharashtra in 2015-16 (Maharashtra Government, 2016) (Refer to Fig-I). It has buses and BRTS as primary public modes of transportation, which are being operated by public utility company named as Pune Mahanagar Parivahan Mahamandal Limited (PMPML), formed in 2007 and serves around 10 lakh passengers per day (Pune Mahanagar Parivahan Mahamandal Ltd, n.d.). As per the comparison of 2012-13 score card of PMPML with 2010-11 score card, which was evaluated on the basis of people's perspectives on four parameters - reliability, comfort, convenience and 
affordability - it was observed that there was some improvement in the overall grade from $\mathrm{C}$ to $\mathrm{B}$ with a score 56 out of 100 . The number of buses per one lakh population had not yet reached, as it stood at 24.8 buses per one lakh population in 2012-13 and the standards given by the Comprehensive Mobility Plan include a target of 55 buses and Transport norms a target of 40 buses per one lakh population (Parisar, 2012). The state of transport system is therefore found to be unsatisfactory as it lacks important factors such as frequency, staff empathy, accessibility, maintenance, cleanliness and inefficiency to meet growing demand (running with just 1338 fleet of buses on road as against ideal size of 3000 buses) (Pune Mahanagar Parivahan Mahamandal Ltd, n.d.). Thus, it becomes immense important for Pune city to invest in improving the condition of public transport and NMT, to reduce exponential growth of private transport modes, congestion and vehicle pollution.

Additionally, PMPML has been running into huge losses. It recorded a loss of Rs. 244.55 crores in the last financial year of 2018-19. Based on the resolution passed in 2014 by Maharashtra State government, PMC and PCMC are asked to share and support operational losses in the ratio of 60:40 respectively. It is therefore, necessary to invest in improving the efficiency of PMPML bus services so as to make it reliable, affordable and sustainable, thereby shifting private mode users to buses and hence increasing the revenue earned through rising ridership (Umbrajkar, 2018).

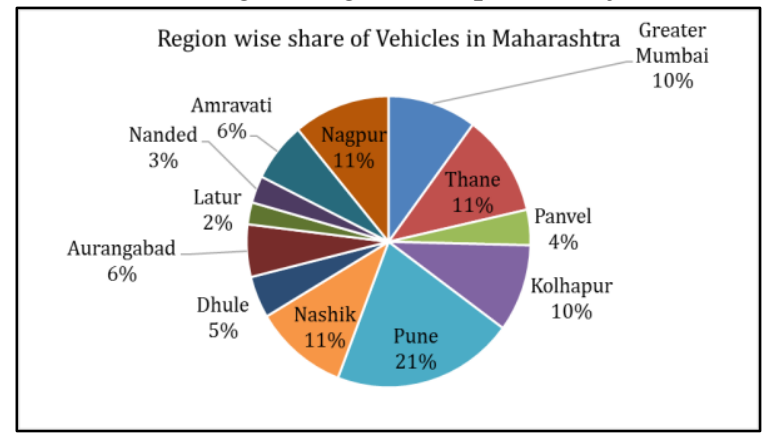

Fig-I: Region wise share of Vehicles in Maharashtra as on $31^{\text {st }}$ March 2016.

Source: (Maharashtra Government, 2016).

The two major objectives of this study are as follows: -

a) To study and analyze the budget allocation of PMC with respect to urban transportation heads and towards the growth of sustainable modes of transport system.

b) To come up with relevant solutions and recommendations pertaining to innovative methods of financing transport projects for the city.

\section{LITERATURE REVIEW}

Transport is the life and blood of the cities (The World Bank, 2002) and provides access to work, education, leisure and other services. To help the cities to work efficiently, it is necessary that resources are used judiciously, that predominantly depends on the mobility of people and goods. Transport system that fails to provide this, influences the growth and development mechanism of the economy (Padam and Singh, 2001). Hence policies should be framed per one lakh population and as per Central Institute of Road

in accordance to provide a transport system, which is reliable, affordable, safe, comfortable and accessible to all.

The demand for transport has been rising in most of the Indian cities and has been experiencing growth of motorised transport modes such as two-wheelers and cars as noted by (Deb, 2002; Kumar et al., 2015). However, growth of public transport and non-motorised transport has not been able to keep a pace with growing demand for mobility (Chakrabartty and Gupta, 2015).

This phenomenon has led to increase in cost for transportation to the citizens and destruction of the society such as congestion, fuel loss, air and noise pollution, productivity loss in terms of time, parking shortage and road accidents (Sen et al., 2010).

The United Nations SDG - 11.2 discusses about providing safe, affordable, accessible and sustainable transport system, which is inclusive to all, notable by expanding public transport by 2030 (Sustainable Development Goals, 2015). In line with that, NUTP also supported the improvement of public transport and NMT modes.

In India, with the enactment of Road Transport Corporation Act in 1950, the State Transport Undertakings (STUs) was given the task of procuring and operating the buses. However, with the new guidelines of Jawaharlal Nehru Urban Renewal Mission (JNNURM) in 2005 and NUTP in 2006, STUs are required to form a city specific body called Special Purpose Vehicle (SPV). These SPVs are responsible for managing the city bus transport system and function with the aim of improving the accountability and efficiency of transport undertakings. In order to procure funds for buses under JNNURM, they had to prepare a detailed project report stating the requirement of buses, planning, infrastructure and financial requirement, maintenance cost, user fees and sustainability of the project (Ministry of Urban Development, 2009). Cities like Pune, Bangalore, Mumbai, Delhi, etc. have a separate SPV, running city bus services, whereas, some like Nagpur, Indore, Aurangabad, Nanded have adopted the Public Private Partnership (PPP) model of delivering bus services to commuters. In some states, bus services continue to be governed and operated by STUs, for example in Karnataka, Gujarat, Maharashtra, etc.

The responsibility of constructing roads, flyovers, bus stops, street lighting, parking lots are under the jurisdiction of ULBs with the introduction of $74^{\text {th }}$ Constitution Amendment Act (CAA), in 1992 (Ministry of Human Resource Department, 1992). Although, ULBs are required to undertake building of transportation infrastructure, they are not equipped with adequate finances to provide the same. It has further been criticized that integration of land use planning with transport planning, has not been initiated actively in most of the cities in India, as stated guideline from NUTP.

\section{Financial Challenges faced by ULBs in India:}

Budgeting is a legislative pursuit for all local level governments in India. A municipal budget is an important 
document as it showcases various revenue resources and expenditure heads over a period of one year.

PMC's budget is also divided into two major parts namely revenue and expenditure. Octroi/ LBT, property tax, water tax, building permission charges and grants (from centre) are the main components on the revenue side. The expenditure side includes revenue expenditure, capital expenditure, loan repayment and other miscellaneous expenditure. In the study undertaken, PMC's expenditure on transportation is analyzed (PMC Website, 2014).

The legal framework of the ULBs in India is envisaged in the $74^{\text {th }}$ CAA of 1992 . This act although explicitly defined the functions and responsibilities of the ULBs in the country, it did not specify the sources of revenue that should be reserved for the municipal corporations. Therefore, it led to a complete miss-match between functions and finances of ULBs in India making them heavily dependent on the state governments (Mathur, 2006). Even after 25 years of the Act, the real devolution of funds, functions and functionaries as envisaged in the act, remains an unfinished agenda, as only $26 \%$ of urban India is governed by ULBs (Tandel et al., 2016).

As compared to foreign countries, the aggregate city revenue in India is less than $1 \%$ of the country's GDP, as opposed to $4 \%$ for Poland, 5\% for Brazil and 6\% for South Africa, leaving little chance for cities to fulfill their service responsibilities (Pierce, 2016). Thus, there is a need to focus on improving the finances of ULBs in the country in order to empower them to provide basic urban transportation.

Parisar (2017) has discussed that Pune has been allocating a larger portion of their budget expenditure into transport sector, but they are inclined towards high carbon emission projects and not oriented towards sustainable and zero carbon projects. The right direction of ULBs finances to sustainable transport system is also therefore equally important.

One way of financing urban transportation is by means of grants from central government under various schemes such as JNNURM, Smart City Mission (SCM) and Atal Mission for Rejuvenation and Urban Transformation (AMRUT). Although, the transfers supplement revenues of municipal corporations, they are often associated with a high degree of fluctuations and have in the past been marked by unpredictability and instability. In addition, there is lack of distinction between capital account and revenue account transfers which further lead to confusion on many heads. Therefore, ULBs being increasingly dependent on the higher levels of government is the obvious result (Vaidya, 2009).

The Goods and Services Tax (GST) that was implemented on 1st of July 2017, by the central government subsumed all the local level taxes such as Octroi, Entry Tax, Local Body Tax (LBT), Value Added Tax (VAT), etc. further made ULBs heavily dependent on the state government compensation (Golam, 2017). Octroi / LBT has been the major contributors to the revenue basket of PMC, wherein their percentage contribution has ranged between $33 \%$ to $40 \%$, which accounts for over one third of the tax revenue corpus of PMC. It would therefore suffer a loss in revenue of an average of $36.5 \%$ by subsuming of LBT under GST.

Lastly, financial data on ULBs in India are inaccessible and difficult to capture. The non-availability of data on the finances of the local bodies makes research and analysis difficult. Various government agencies will be blind without adequate urban database and continue to plan and fund urban development needs like six blind men trying to understand an elephant (Joshi, 2014).

Table-II highlights some of the best practices adopted by countries abroad and the innovative methods undertaken to enhance their finances. Singapore and London rely on congestion charges especially in core city areas, as a method to collect revenue, which serves dual purpose - it not only builds revenue for the ULB but also discourages use of private transport in the particular city areas. Additionally, London has also made a distinction between residential and commercial property tax, thereby charging higher prices from commercial properties. Similarly, Frankfurt has introduced local trade tax and Tokyo is charging separate tax for corporates and individuals, to supplement generation of revenue at local level.

Table- II: Showing Innovative Financing Methods used in Top Global Cities

\begin{tabular}{lll}
\hline Sr. No. & City & Innovative Financing \\
\hline $\mathbf{1}$ & $\begin{array}{l}\text { Singapore } \\
\text { and London }\end{array}$ & $\begin{array}{l}\text { Congestion tax - for private cars entering the congestion- } \\
\text { charging zone (can be done for peak hours of the day) }\end{array}$ \\
\hline $\mathbf{2}$ & London & $\begin{array}{l}\text { A distinction is made between residential and commercial } \\
\text { property tax to earn more revenue from commercial } \\
\text { properties. }\end{array}$ \\
\hline $\mathbf{3}$ & Frankfurt & $\begin{array}{l}\text { Local trade tax that is collected for transportation of goods } \\
\text { from one city to another. }\end{array}$ \\
\hline $\mathbf{4}$ & Tokyo & $\begin{array}{l}\text { Metropolitan inhabitants tax separate rates for corporates } \\
\text { and individuals. }\end{array}$ \\
\hline
\end{tabular}

Source: (Slack, 2016).

\section{METHODOLOGY AND DISCUSSION}

To study the budget allocation of PMC on urban transportation, a financial analysis is undertaken for a period of one year (2016-17). This year was particularly selected taking into account the actual figures from the PMC Budget as against budgeted or revised figures. One of the major limitations of the study is that the online budget data of $\mathrm{PMC}$ is in regional language of Marathi, and translating the same into English becomes a challenging task for the researchers.

The following Table-III displays the total expenditure (Rs.3378 cr) of PMC that is divided into four major parts namely revenue expenditure contributing about $42 \%$ of the total expenditure, capital expenditure at $40 \%$, loans repayment at $1 \%$ and other expenditure at $17 \%$.

Table- III: Various Expenditure Heads of PMC (201617) (Figures in Rs. Crores)

\begin{tabular}{llllll}
\hline Years & $\begin{array}{l}\text { Total } \\
\text { Expenditure }\end{array}$ & $\begin{array}{l}\text { Revenue } \\
\text { Expenditure }\end{array}$ & $\begin{array}{l}\text { Capital } \\
\text { Expenditure }\end{array}$ & $\begin{array}{l}\text { Loan } \\
\text { Repayment }\end{array}$ & Others \\
\hline $\mathbf{2 0 1 6 -}$ & 3378 & $1416(42)$ & $1363(40)$ & $40(1)$ & $559(17)$ \\
$\mathbf{1 7}$ & & & & &
\end{tabular}

Source: Collected from PMC office. 
The below Table-IV reveals PMC's expenditure on various transportation services out of the total expenditure of Rs.3378 cr. The major transportation sector heads under PMC include road development, traffic control department, road cleaning, road maintenance, advances to PMPML and BRTS Phase-1 under JNNURM. Under Capital Expenditure, there are two sub-heads namely - road development and traffic control department. Under Revenue Expenditure, there are three sub-heads namely - road cleaning, road maintenance and advances to PMPML. Grants from the central government are given under the program of JNNURM.

Table- IV: PMC's budgetary allocation on transportation (2016-17) (Figures in Rs. Crores)

\begin{tabular}{|c|c|c|c|}
\hline $\begin{array}{l}\text { Sr. } \\
\text { No. }\end{array}$ & $\begin{array}{ll}\text { PMC's } & \text { Transportation } \\
\text { Expenditure } & \end{array}$ & $\begin{array}{l}\text { Amounts } \\
\text { (in crore) }\end{array}$ & $\begin{array}{l}\text { Percentage } \\
\text { Contribution }\end{array}$ \\
\hline 1 & Road Development & 545.88 & \\
\hline \multirow[t]{2}{*}{2} & Traffic Control Department & 80.03 & \\
\hline & Sub Total (Capital Expenditure) & 625.91 & $(45.9 \%)$ \\
\hline 3 & Road Cleaning & 184.98 & \\
\hline 4 & Roads Maintenance & 325.3 & \\
\hline \multirow[t]{2}{*}{5} & Advance to PMPML & 193 & \\
\hline & Sub-Total (Revenue Expenditure) & 703.28 & $(49.6 \%)$ \\
\hline \multirow[t]{2}{*}{6} & JNNURM BRTS Phase-1 & 2.45 & \\
\hline & Total Transportation Expenditure & 1331.64 & $(39.42)$ \\
\hline
\end{tabular}

Source: Author's Calculation.

The transport heads described in the budget are categorized by authors into general transportation head catering all kinds of transport modes such as road development, traffic control department, road cleaning and road maintenance. Other category is sustainable transportation head, which includes advance to PMPML and JNNURM BRTS. Tables- V and VI aim to assess the expenditure on transportation from the total budget on PMC on these two categories namely general and sustainable transportation head.

Table- V: PMC transport expenditure allocation to general heads (in Rs. crores)

\begin{tabular}{|c|c|}
\hline \multicolumn{2}{|l|}{ Category 1} \\
\hline General Head & Amount \\
\hline Road Development & 545.88 \\
\hline Traffic Control Department & 80.03 \\
\hline Road Cleaning & 184.98 \\
\hline Roads & 325.3 \\
\hline Total of general head & 1136.19 \\
\hline Total transpout expenditure & 1331.64 \\
\hline Percentage of general head to total transportation erpenditure & $85.32 \%$ \\
\hline
\end{tabular}

Source: - PMC Budget (2016-17).
Table- VI: PMC transport expenditure allocation to sustainable transport heads (in Rs. crores)

\begin{tabular}{|l|r|}
\hline \multicolumn{2}{|c|}{ Category 1 } \\
\hline General Head & Amount \\
\hline Road Development & 545.88 \\
\hline Traffic Control Department & 80.03 \\
\hline Road Cleaning & 184.98 \\
\hline Roads & 325.3 \\
\hline Total of general head & 1136.19 \\
\hline Total transport expenditure & 1331.64 \\
\hline Percentage of general head to total transportation expenditure & $85.32 \%$ \\
\hline
\end{tabular}

Source: PMC Budget (2016-17).

\section{FINDINGS AND ANALYSIS RESULTS}

From the above Table-IV out of the total expenditure, PMC spends about $39 \%$ on transportation, which should vary between $20 \%$ to $40 \%$ according to Parisar (2017) for an ULB to provide sustainable urban transportation. On this ground, the PMC is performing in line with the required financial contribution. In terms of capital expenditure on transportation that stands at $45 \%$, but which should vary between $40 \%$ to $90 \%$, PMC marginally makes it within the required range, therefore suggesting that there is a wide scope of improvement in increasing the capital expenditure on providing sustainable urban transportation in the city. These gaps in finances of up to $20 \%$ with an enhanced limit of up to $30 \%$ for rail-based projects or bus transit system projects can be funded through PPP and has been done in many developed countries across the world (Purandare \& Pandurangi, 2018).

Additionally, the Tables-V and VI depicts that majority of total transport expenditure is allocated to catering the needs of all modes of transport (85.32\%) including private transport modes. And that a lower proportion of funds is dedicated to sustainable modes of transport such as public transport. Interestingly, no such category was found in the budget, which is catering to the enhancement of NMT infrastructure in the total transport expenditure. Considering examples of other smart cities (as shown in table 2), they rely on charging private vehicles in the form of congestion tax for using the road space and they use the collected tax in the improvement of sustainable modes of transport and transport development projects.

\section{CONCLUSION}

The study concludes, by stating the fact that, ULBs (including PMC), which are already financially week, are further made heavily dependent on the state governments with the introduction of GST in July 2017. PMC's financial assistance to PMPML is relatively less as compared to investments in other transport heads such as roads, roads cleaning, maintenance, etc. PMC's expenditure on other transport utilities is undoubtedly benefiting sustainable modes as well, but it is more effectively catering more to the needs of private transportation users, as they occupy the larger share of Pune roads. Unfortunately, NMT and

Published By:

Blue Eyes Intelligence Engineering

\& Sciences Publication 
infrastructure required for NMT do not have separate head featured under the PMC budget. Hence, innovative financing on specific sustainable modes rather than on general transport utilities is imperative for the long run growth of the economy and has been followed in most of the world's smart and livable cities like Singapore, London and Curitiba. PMC thus, needs to focus on two major items namely; innovative transport financing options and focusing on investing heavily in sustainable urban transportation rather than on general mode of transportation. This will not only make cities financially better off but will also help to improve the overall transportation systems and reduces the external cost of transportation to the society at large.

\section{RECOMMENDATIONS}

A. ULB should focus or channelize more funds towards financing infrastructure for sustainable mode of transport such as public transport and NMT modes. In addition to that, they need to promote fuel-efficient personal vehicles such as electric vehicles, CNG vehicles and invest in other innovative fuel-efficient solutions.

B. One of the ways to finance transportation is to implement PPP, where in the private player could not only bring in the much-needed finances but also help is managing and improving the transportation systems in Indian cities (Vaidya, 2009). A PPP model of transportation is seen to work very successfully in Nagpur City of Maharashtra.

C. Another way of financing the transportation is by means of pooled financing. Generally, small and mediumsized ULBs do not have access to funds from the capital markets. In this case, pooled financing options encourage state governments and small to medium-sized ULBs to pool their (transportation) projects together and achieve a marketable size of finances (Khan, 2013). A similar kind of pooled transportation is carried out between two ULBs of Pune (PMC) and Pimpri Chinchwad (PCMC) wherein they formed a company together - PMPML - which is responsible for providing bus transport in both the cities. In this case PMPML will be able to access more funds as compared to, if PMC or PCMC were supposed to access them as individual identities.

D. Developmental charges / fees can also be used as one way to generate revenue and fund local area transportation, particularly in new areas being developed under the areas covered by ULBs. Financing services through developmental charges provides funds with which supply of services is possible (Rao \& Bird, 2010). For example, if buses are provided in a particular area of a city then only those directly benefiting from the bus service will be charges a developmental charge / fees. Developmental charges as a one-time levy has widely been used in USA and Canada (Bagchi, 2006).

E. To avoid congestion on roads, a congestion charge scheme can be used. It is a simple system where a daily charge is levied by the local government for entering a particular congestion-creating zone within a city. This serves two purposes - firstly it discourages people to use their private vehicles in the congestion zones and instead use public transport and secondly, it also builds revenue for the ULB. One of the most famous example for levying high congestion charges can be seen in London from 2003 onwards (Timms, 2013; Badstuber, 2018). A similar congestion tax model is followed in Singapore as well (Phang \& Toh, 2004).

\section{REFERENCES}

1. Badstuber, N. (2018, April 11). London's Congestion Charge Is Showing Its Age. Retrieved July 29, 2018 from https://www.citylab.com/transportation/2018/04/londonscongestion-charge-needs-updating/557699/

2. Bagchi, A. (2006, December). Local Revenue Administration. New Delhi, Delhi, India: NIPFP.

3. Census Population 2015 Data. (2011). Pune City Census 2011 data. Retrieved 2019 from census2011: https://www.census2011.co.in/census/city/375-pune.html

4. Chakrabartty and Gupta. (2015). Estimation of Congestion Cost in the City of Kolkata-A Case Study. Current Urban Studies , 95-104

5. Deb, K. (2002). Restructuring Urban Public Transport in India. journal of Public Transportation , 85-102.

6. Golam, L. (2017, July 15). Implication of Goods and Service Tax (GST) On the Fiscal Autonomy of ULBs. Mumbai, Maharashtra, India.

7. Joshi, R. (2014). Addressing Financial Needs of ULBs A Tale of Six Blind Men And An Elephant. India.

8. Khan, H. R. (2013, July 18). Financing Strategies for Urban Infrastructure: Trends and Challenges. From Reserve Bank on India: https://www.rbi.org.in/scripts/BS_SpeechesView.aspx?Id $=824$

9. Kumar et al. (2015). Non-Motorised Transport Policy in India. Eschborn ,Germany: Deutsche Gesellschaft fur Internationale Zuammenarbeit (GIZ) GmbH .

10. Maharashtra Government. (2016). Information on Maharashtra. Maharashtra Government.

11. Mathur, O. P. (2006). Urban Finance. Mumbai: India Infrastructure Report.

12. Ministry of Human Resource Department. (1992). The Constitution (Seventy-Fourth Amendment) Act, 1992. Ministry of Human Resource Department.

13. Ministry of Urban Development. (2009, January 2). Funding for purchase of buses for urban transport systems under JnNURM. From Author: http://moud.gov.in/upload/uploadfiles/files/buses_fundin g.pdf

14. MoUD. (2015, April). The Future of Urban Development and Services: Urban Development Recommendations for Government of India. Retrieved July 19, 2017 from World Economics Forum: http://www3.weforum.org/docs/WEF_IU_FUDS_Urban Development_Recommendations_Government_India_Re port_2015.pdf

15. National Urban Transport Policy. (2006). National Urban Transport Policy. New Delhi: Government of India.

16. Parisar. (2012). PMPML Report Card 2012-13. Retrieved 2016 from PMPML Report Card 2012-13 http://www.indiaenvironmentportal.org.in/files/file/PMP ML\%20Report\%20Card.pdf

17. Parisar. (2017). Transport Budget Analysis in 5 Indian Cities: Understanding the relationship between city budgets and sustainable transport objectives. Sustainable Urban Mobility Network.

18. Phang, S. Y., \& Toh, R. S. (2004, March). Road Congestion Pricing in Singapore: 1975-2003. Retrieved 
July 29, $2018 \quad$ from https://ink.library.smu.edu.sg/cgi/viewcontent.cgi?article $=1116 \&$ context $=$ soe_research

19. Pierce, G. (2016). Fiscal Transfers and Urban Policy: Magnitude and Mechanisms of Urban Dependency. Economic \& Political Weekly (EPW), II (42), 44-52.

20. PMC Website. (2014). Pune Municipal Corporation. From Pune Municipal Corporation Website: http://www.punecorporation.org/about_us.aspx

21. Pune Mahanagar Parivahan Mahamandal Ltd. (n.d.). Pune Mahanagar Parivahan Mahamandal Ltd. Retrieved April 27, 2019 from Pune Mahanagar Parivahan Mahamandal Ltd: https://www.pmpml.org/

22. Pune Municipal Corporation. (2012). Revised City Development Plan (CDP) of Pune City- 2041. Pune: Pune Municipal Corporation.

23. Pune Municipal Corporation. (n.d). Pune City Population. From Pune Municipal Corporation: https://pmc.gov.in/en/census

24. Purandare, J., \& Pandurangi, A. (2018). Urban transportation financing A strong case for public-private partnership. PCMC, Maharashtra, India.

25. Sen et al. (2010). Estimating marginal external costs of transport in Delhi. Transport Policy, 17-37.

26. Slack, E. (2016, October). International Comparison of Global City Financing - A Report to the London Finance Commission . Retrieved July 29, 2018 from International Comparison of Global City Financing - A Report to the London Finance Commission https://munkschool.utoronto.ca/imfg/uploads/236/lfc_inte rnational_comparisons.pdf

27. Sustainable Development Goals. (2015). Sustainable Development Goal 11. Retrieved 2019 from sustainabledevelopment.un.org: https://sustainabledevelopment.un.org/sdg11

28. Tandel, V., Hiranandani, K., \& Kapoor, M. (2016, July 28). What's In A Definition?: A Study on Implications and Suitability of Urban Definitions in India through its Employment Guarantee Programme. Retrieved May 18, 2017 from IDFC: http://www.idfcinstitute.org/site/assets/files/9615/tandel_ et_al_28th_july_whats_in_a_definition.pdf

29. The World Bank. (2002). Cities on the move. Washington DC : The World Bank.

30. Timms, C. (2013, Feberury 15). Has London's congestion charge worked? Retrieved July 29, 2018 from Has London's congestion charge worked? https://www.bbc.com/news/uk-england-london21451245

31. Umbrajkar, M. (2018, December 30). PMPML asks civic bodies to bear losses of Rs 244 crore. Retrieved May 23, 2019 from Times of India: https://timesofindia.indiatimes.com/city/pune/pmpmlasks-civic-bodies-to-bear-losses-of-rs-244crore/articleshow/67305274.cms

32. Vaidya, C. (2009). Urban Issues, Reforms and Way Forward in India. Ministry of Finance, Government of India, Department of Economic Affairs. Government of India.

33. World Population Review. (2019). Population of Cities in India (2019). From World Population Review: http://worldpopulationreview.com/countries/indiapopulation/cities/

34. Zope, R. (2013). The Planning Strategies for Urban Land Use Pattern: A Case Study of Pune City, India. International Journal of Innovative Research in Science, Engineering and Technology-Vol. 2, Issue 7 , 2682-2687.

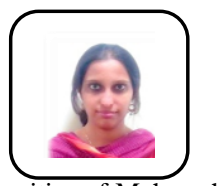

\section{AUTHORS PROFILE}

Dr. Aanchal Airy, as First Author, is an Assistant Professor at the Symbiosis School of Economics (SSE), located in Pune City, India. She has completed her PhD in Urban Transport, which aimed to assess the quality of public urban transport with respect to Pune and Nagpur cities of Maharashtra State (India) and M.Sc. in Economics (Specialization in International Trade) from the Symbiosis International (Deemed University). She has one book chapter publication with IGI global indexed in SCOPUS and titled as 'Urbanization and Socio-economic growth in South Asia Region'. Another research paper titled 'Urban Transport Policy in India: A Review' in International Journal of Public Sector Performance Management indexed in ABDC and SCOPUS. She has also been involved in consultancy projects in the area of congestion pricing in Mumbai and Smart City Assessment of Pune and Nashik. Her area of research includes: Urban Transport, Land Economics, Urbanization, Public Policy and Research Methodology.

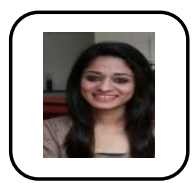

Gargi Patil, as Second Author, is a Visiting Faculty at the Symbiosis School of Economics (SSE), located in Pune City, India. She is also pursuing PhD in Economics with specialization in Urban Finance at the Symbiosis International (Deemed University) and is in her final year. She has completed her Masters degree in Economics and Bachelors degree in Economics, both from Fergusson College, Pune. She has recently published a book chapter with IGI Global titled "Crowd funding - Can it Support Urban Local Bodies in India?" which is indexed in SCOPUS. She has also been actively involved with several conferences and faculty development programs. Her areas of research include: Urban Finance, Public Policy and Micro Economics. 